\title{
Investigating Consumer Demand and Willingness to Pay for Fresh, Local, Organic, and "On-the-Stalk" Edamame
}

\author{
Nick Lord ${ }^{1}$, Bo Zhang ${ }^{1}$ and Clinton L. Neill ${ }^{2 *}$ \\ ${ }^{1}$ School of Plant and Environmental Sciences, Virginia Tech, Blacksburg, VA, United States, ${ }^{2}$ Department of Population \\ Medicine and Diagnostic Sciences, Cornell University, Ithaca, NY, United States
}

\section{OPEN ACCESS}

Edited by:

Giuseppe Di Vita,

University of Turin, Italy

Reviewed by:

Daniela Spina

University of Catania, Italy

Timothy Woods,

University of Kentucky, United States

${ }^{*}$ Correspondence:

Clinton L. Neill

cln64@cornell.edu

Specialty section:

This article was submitted to

Nutrition and Sustainable Diets,

a section of the journal

Frontiers in Sustainable Food Systems

Received: 10 January 2021

Accepted: 31 July 2021

Published: 31 August 2021

Citation:

Lord N, Zhang B and Neill CL (2021) Investigating Consumer Demand and Willingness to Pay for Fresh, Local,

Organic, and "On-the-Stalk"

Edamame.

Front. Sustain. Food Syst. 5:651505.

doi: 10.3389/fsufs.2021.651505
Introduction of locally adapted, commercially viable edamame varieties can allow it to be marketed as fresh, local, organic, or on the stalk. Here, we utilized a one-and-one-half bounded $(\mathrm{OOHB}$ ) elicitation format to estimate mean willingness to pay (WTP) for these external attributes in relation to a vector of explanatory variables. Results showed 84-, 85-, and 28-cent premiums for fresh, local, and organic edamame (10 oz). Pro-environmental attitudes drove WTP for all three of these attributes, while shopping location significantly increased mean WTP for fresh and organic attributes. A 40-cent price discount was observed for the "on-the-stalk" attribute, suggesting that convenience also plays an important role in marketing edamame. The results suggest that more research regarding edamame demand is warranted.

Keywords: consumer preference, economics, willingness to pay, edamame, organic, local, one-and-one-half bound dichotomous choice

\section{INTRODUCTION}

As Americans become more health and/or environmentally conscious, there is a growing desire among consumers to reduce meat consumption, which has led to noticeable growth in demand for alternative, plant-based sources of protein (Bashi et al., 2019). In addition, the disproportionately large and rapid growth of Asian populations in the United States promises to create new market opportunities for specialty Asian produce (Govindasamy et al., 2010). Vegetable soybean, more commonly referred to as edamame (pronounced "eh-duh-MAH-may"), has quickly emerged as a prime candidate to capitalize on both of these domestic trends, appearing more and more frequently in salad bars and sushi restaurants nationwide.

Edamame has a long history of consumption in East Asia (Shurtleff and Aoyagi, 2009) where the industry has become well-established. It was not until the turn of the 21st century that it began to be imported to U.S. markets. In order to meet domestic demand, roughly 25,000 to 30,000 tons of edamame is consumed annually (CBS News, 2013), which is predominantly met through frozen imports sold to consumers year-round in grocery stores. In the United States, edamame is most commonly supplied as pods, where consumers suck the beans out of the pod. Edamame can also be supplied as shelled beans that have already been removed from the pods.

Soybean proteins contain all essential amino acids that are required for human growth and development, which earned them the designation of being a high-quality protein source (Michelfelder, 2009). In addition, several studies have suggested that soy consumption can reduce levels of low-density lipoprotein (LDL) cholesterol, or "bad" cholesterol, in the body, which can 
build up in arteries and increase risk of cardiovascular disease (Hasler, 2002; Taku et al., 2007). As legumes, soybeans also exploit biological nitrogen fixation, which reduces the need for synthetic nitrogen application and is beneficial for soil health (Beyan et al., 2018). This unique combination of nutritional and environmentally friendly characteristics has allowed edamame to carve out a distinguished position in the domestic marketplace for vegetables.

Edamame's growing popularity has sparked interest in bolstering U.S. edamame production to reduce reliance on imports and to allow domestic growers to capitalize on edamame's premium market position. In the coming years, plant breeders are set to release seed inputs adapted to U.S. production regions with higher yield potential, enhanced sensory quality, and increased suitability for mechanized harvest in hopes of catalyzing domestic production (Lord et al., 2019b). The provision of locally adapted seed inputs can lead to many new edamame product options in the domestic marketplace.

With more edamame grown on U.S. soil, edamame producers and distributors can seek to access premiums associated with quality-differentiated external attributes such as being freshly supplied, locally grown, and USDA certified organic or market it as an alternative end product. As such, this study seeks to understand what marketing advantage, if any, these attributes hold over the frozen, imported, and non-GMO products that are currently available to consumers today.

\section{LITERATURE REVIEW}

Consumption of fresh produce in the United States has considerably grown as selection and quality of fresh vegetables in the marketplace have increased (Pollack, 2001). Consumer preference for fresh produce can be largely attributed to perceived losses in nutritional quality from blanching and freezing that is associated with frozen produce (Heinrichs, 2016). In the case of edamame, several studies have suggested relatively low production costs and the potential profitability of fresh market edamame (Shockley et al., 2011; Sharma, 2013; Garber and Neill, 2019; Lord et al., 2019a). However, it is unclear how much more consumers would value a fresh, seasonal edamame product over the frozen edamame available in most grocery stores.

The local food market continues to occupy an increasingly important share of agricultural sales in the United States. Though "local food" remains a loosely defined concept, it generally refers to food produced within close geographical proximity to consumers and which also contains certain social and supply chain distinctions related to production practice, environmental impact, food safety, fair labor practices, and animal welfare (Martinez, 2010; Holcomb et al., 2018; Neill et al., 2020). Numerous studies have demonstrated that consumers are willing to pay price premiums for food labeled as locally grown, which can be primarily attributed to perceived improvements in quality, nutrition, and value for price, as well as support for local economies, concern over environmental impact, and demographic characteristics (Brown, 2003; Carpio and Isengildina-Massa, 2009; Martinez, 2010; Wang et al.,
2010; Feldmann and Hamm, 2015; Neill and Williams, 2016). Moreover, a recent study by Fan et al. (2019) suggests that these premiums may be irrespective of actual quality or flavor. Edamame is different than most of the produce items that have been previously studied for the local attribute, given its origins in East Asia and the predominance of imports used to meet U.S. demand. To date, no studies have yet been conducted to understand how consumers would value a locally grown edamame product compared to the non-local, imported edamame products that are already available to consumers.

At the same time, the purchase of organic vegetables has drastically risen in the United States over the past few decades, with its consumer base becoming increasingly diverse (Stevens-Garmon et al., 2007; Dettmann and Dimitri, 2009). In 2003, the USDA established the National Organic Program (NOP), which regulates organic marketing by certifying that products are produced in accordance with a set of approved inputs and substances that are consistent with regenerative and sustainable agricultural principles. As a result of the myriad provisions guaranteed by the NOP and the additional cost to obtain certification, organic produce often commands substantial premiums in the marketplace. Interestingly, evidence suggests that many consumers may not necessarily value all provisions of the USDA Organic label equally. Some, for example, are only willing to pay more for the guaranteed use of non-GMO seed inputs but are not necessarily concerned about which synthetic fertilizers and pesticides are used during production. To test this hypothesis, Bernard et al. (2006) conducted a study intended to mimic market conditions by observing subjects in an experimental auction setting where they were asked to indicate their willingness to pay (WTP) for various food items that fall under conventional, organic, and non-GMO categories. While overall results showed the highest WTP estimates for food items in the organic category, further analysis revealed that beyond the non-GMO attribute, subjects did not appear willing to pay significantly extra for the remaining attributes of the organic category. No studies have yet explored consumer WTP for USDA-certified organic edamame; however, a recent study by Wolfe et al. (2018) demonstrated that non-GMO edamame may already hold some appeal to consumers with risk aversion to GMO products and that this may even compensate for shortcomings in sensory quality. To this end, a gap exists in the understanding of how consumer WTP for organic edamame is affected by the presence of non-GMO edamame, which is already common in the marketplace. Such findings are crucial to more completely understand the potential of USDA-certified organic edamame in the United States.

Growing consumer inclination for convenience has become increasingly important in consumer food purchasing decisions in recent years (Pollack, 2001; Brunner et al., 2010). The term convenience encompasses time, physical, and mental effort associated with meal preparation and has been shown to be positively correlated with a number of socioeconomic and attitudinal variables including household size, working status, and cooking enjoyment among others (Candel, 2001; Brunner et al., 2010). Interestingly, Lockie et al. (2004) found that concern for convenience was negatively correlated with 
consumption of organic food, of which naturalness of the product was a particularly strong predictor. These findings were later corroborated by Brunner et al. (2010), who found that naturalness was a consistently strong, negative predictor for consumption of highly processed, minimally processed, and single-component food categories. "On-the-stalk" edamame is an ideal candidate to study the competing influence of naturalness with convenience on consumer WTP. In whole plant or "on-thestalk" end product, pods are still attached to the branches or stalks of the plant, making for an end product that appears considerably more natural (Figure 1). Marketing edamame as an "on-thestalk" end product is more common in Japan, where many consumers actually prefer it supplied in this way for its perceived added freshness (Born, 2006). By observing consumer WTP for "on-the-stalk" edamame, which decreases convenience by requiring consumers to pick the pods off of the stalks themselves, in comparison to pre-stripped edamame pods that require much less preparation time and are already common in U.S. markets, we can also gain insight into the role that convenience plays in consumer WTP for edamame.

Other studies have shown that social-altruistic and biospheric value bases have translated to higher WTP for regional and organic products (Umberger et al., 2009; Rahman and Reynolds, 2017; Shin et al., 2017). In addition, Onozaka et al. (2011) contend that shopping location may also influence consumer valuation for various labeling campaigns by indirectly sorting consumers based on the different sustainability claims made instore or within the market venue. Moreover, the hierarchical nature of consumer preferences is an important aspect of the demand issue that often leads to clustering of consumers (Di Vita et al., 2021). Information on how these factors, as well as many other explanatory variables relating to demographic information, dietary habits, and personal beliefs, affect consumer WTP also remains poorly understood. As such, the goal of this work was to use contingent valuation (CV) methodology to (1) estimate mean WTP for edamame marketed as fresh, local, USDA Organic, and "on the stalk" and (2) identify significant explanatory variables that influence these estimates in order to better understand the potential of alternatively marketed edamame in the United States.

\section{DATA AND METHODS}

$\mathrm{CV}$ is a flexible survey technique used to estimate WTP for non-market goods and services (Lopez-Feldman, 2012). It has been frequently exploited in the literature to forecast success or demand for various agricultural products, ecolabels, and marketing trends (Carpio and Isengildina-Massa, 2009; Haghiri et al., 2009; Owusu and Owusu Anifori, 2013; Neill and Williams, 2016). CV methodology can be particularly useful in exploring price premiums and WTP for products or product attributes that have yet to appear in the marketplace. This is achieved by presenting participants with a hypothetical scenario through which to observe their purchasing decisions when both the "status-quo" and newly proposed product or attribute of interest are present. CV methods are also ideal for consumer intercept surveys, like this study, to keep questionnaires short when presented on paper. While this does risk some hypothetical bias, Penn and $\mathrm{Hu}$ (2018) noted that the bias is not as large as that present in auction methods. However, a choice experiment or referendum experiment would likely have reduced hypothetical bias further.

While edamame is already in the market, the specific attributes inquired about via our study are not overtly available. In particular, edamame is commonly found as frozen, in pods or shelled bean form, and often imported. As much as $80 \%$ of edamame is imported to meet a growing domestic demand, which means that the majority is frozen to remain edible (Bernick, 2009; Wolfe et al., 2018). This also means that it is rarely found "on the stalk," fresh, or local. While some edamame is sold as USDA certified organic, it is unknown if this marketing label is preferred over the alternative of non-GMO. All edamame is produced as non-GMO as there are no commercial GMO varieties. In addition, domestic edamame production is on the rise, particularly in Arkansas, given the proximity to proper processing facilities (Jaeger, 2019).

During the month of October 2018, consumer intercept $\mathrm{CV}$ surveys (on paper as consumers entered the store) were distributed at three primary locations in Blacksburg, VA-Oasis International Supermarket, the Blacksburg Farmer's Market,
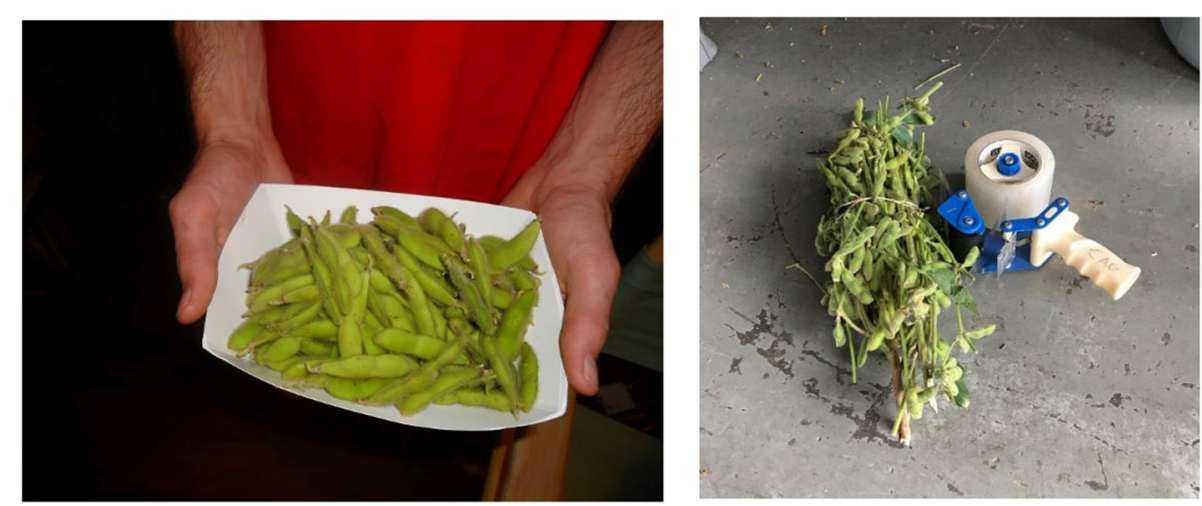

FIGURE 1 | Pictures of edamame end products. Edamame supplied as pre-stripped pods is predominantly consumed in the United States today, while edamame supplied as "on the stalk" (right) is more commonly preferred in East Asia for its added freshness. 
1. What is your current age? Under $18 \quad 18$ to $30 \quad 30$ to $45 \quad 46$ to 50 Older than 60

2. What gender do you identify with? Male Female Other

3. What is your ethnicity?

Caucasian African American Asian Hispanic Other

4. Are you the main shopper for your household? Yes No

5. What is your current household family size, including yourself?
1
2
3
4
More than 4

6. How many meals do you eat at home per week?
1 to 5
6 to 10
11 to 15
16 or more

7. What is your current level of education?

Some school High school diploma Some college Bachelor's degree Advanced degree

8. What is your household income?

Less than $20,000 \quad 20,000-35,000 \quad 35,001-50,000 \quad 50,001-70,000 \quad 70,001-100,000 \quad 100,000+$

9. How many days a week do you consume meat (including fish)?

$\begin{array}{llllllll}0 & 1 & 2 & 3 & 4 & 5 & 6 & 7\end{array}$

10. Do you have any desire to reduce your meat consumption? Yes No

10a. If you answered "yes" to question 10, please check which reasons you desire to reduce meat consumption:_ _ health _ religious reasons _reduce environmental impact _ other 11. Are you full/partially vegan or vegetarian? Yes No

12. On a scale of 1 to 5 with 1 being never and 5 being very often/always, how often do you purchase food that is labeled organic, free range/cage free, Rainforest Alliance, Wild Caught, natural, or nonGMO? $\quad \begin{array}{llllll}1 & 2 & 3 & 4 & 5\end{array}$

FIGURE 2 | Example of demographic questions on survey instrument.

and the Virginia Tech Squires Student Center. Other survey locations were also utilized but in much smaller quantities and are classified as "other." Surveys consisted of 20 questions each. The first 16 questions pertained to demographic information and characteristics of participants relating to purchasing habits, environmental attitudes, dietary habits, and familiarity with edamame (Figure 2). The location of survey was included as a categorical variable in order to also observe the effect of market venue. Responses to these questions were used to identify important explanatory variables of mean WTP.

The remaining four questions were used to elicit WTP using dichotomous-choice (DC) questions. Specifically, consumers evaluated fresh vs. frozen, local vs. imported, organic vs. nonGMO, and "on the stalk" vs. pods of edamame in the four DC questions. This can also be seen in Table 1. Each DC question was asked independently of each other. More importantly, as previously mentioned, each one had a specific and status quo option relevant to the attribute of interest-fresh vs. frozen, local vs. non-local, ${ }^{1}$ organic vs. non-GMO, and on the stalk vs. pods. An example of the one-and-one-half bounded (OOHB)-DC questions can be seen in Figure 3. In these questions, respondents must choose between purchasing the "status quo" option, which is always listed at the "fair" price (in this case $\$ 3.50$ per $10 \mathrm{oz}$ of pods) or the new or alternatively marketed product of the same quantity when it is offered at a premium. In order to get information on multiple premiums, three survey versions were randomly administered, each only differing in the extent of the premium for the alternative product. One of the three versions

\footnotetext{
${ }^{1}$ Note that we did not define local for the participants. This could have caused additional hypothetical bias, but we did not want to define a geographical boundary given that all of the participants were from one particular town.
} 
TABLE 1 | Alternatives in each of the OOHB-DC CV questions.

\begin{tabular}{lll}
\hline Question & Attribute of interest & Status quo option \\
\hline 1 & Fresh & Frozen \\
2 & Local & Imported \\
3 & Organic & Non-GMO \\
4 & On the stalk & Pods \\
\hline
\end{tabular}

also offered the alternative product at a lower price than the status quo to see if participants actually discounted the alternative product. In total, premiums of $0.25,0.50$, and 1.00 and a discount of 0.25 were observed. For each survey version, all four DC questions had the same premium/discount associated with the attribute. For example, the same participant was asked to choose between fresh and frozen edamame at a premium of $\$ 0.50$ and was asked their choice between non-GMO and organic edamame also at a premium of $\$ 0.50$.

DC questions are regarded as the most adequate, reliable, and heavily utilized CV elicitation technique used in the literature, given their increased statistical efficiency and reduced response bias over other CV elicitation methods such as open-ended questions and payment cards (Venkatachalam, 2004; LopezFeldman, 2012). As opposed to DC questions, single-bounded questions consisting of a single "take-it-or-leave-it" question simply ask the individual whether they would accept $\left(y_{i}=\right.$ 1) or reject $\left(y_{i}=0\right)$ a bid for the product/attribute of interest. To increase the statistical efficiency of the singlebounded estimation, Hanemann et al. (1991) later proposed the addition of a follow-up question dependent on the response to the initial question. Responses to initial and follow-up questions can be captured by dichotomous variables $y_{i}^{1}$ and $y_{i}^{2}$, respectively. If the individual selects "no" to the initial bid $\left(y_{i}^{1}=0\right)$, a lower bid is offered, whereas if the individual selects "yes" $\left(y_{i}^{1}=1\right)$, then a higher bid is offered. Despite its increased statistical efficiency, discrepancies observed between the initial and follow-up questions of the DB format have caused concern over its consistency and reproducibility. The OOHB question format was thus developed to address this response bias while maintaining statistical efficiency (Cooper et al., 2002). In OOHBDC questions, respondents are only asked to answer a followup if they select "yes" for the bid listed in the initial question. Responses to OOHB-DC questions can therefore result in one of the following three scenarios: no-no, yes-no, or yes-yes.

An interval data model was used to estimate individual WTP as a function of explanatory variables and error. The probability that the WTP falls between specific minimum and maximum bounds can be estimated using a log-likelihood function. To understand the econometric estimation behind the probabilities for each of the aforementioned scenarios, let us consider the following set of equations, taken from Neill and Williams (2016):

$$
\begin{aligned}
\operatorname{WTP}_{i}\left(z_{i}, u_{i}\right) & =z_{i} \beta+u_{i} \\
\operatorname{Pr}\left(y_{i}^{1}=1, y_{i}^{2}=0 \mid z_{i}\right) & =\operatorname{Pr}(s, n)
\end{aligned}
$$

In equation 1, we assume WTP is a function of an individual's characteristics (demographics, environmental attitudes, diet, etc.) plus error, where $z_{i}$ represents a vector of explanatory variables, $\beta$ represents a vector of coefficients for the explanatory variables, and $u_{i}$ represents an error term. Equation (2) represents a simplified notation for the probability of an individual answering "yes" to the initial question and "no" to the followup, dependent on the vector of explanatory variables. Under the assumptions of Equation 1 and that our data are normally distributed, we can obtain the following:

$$
\begin{aligned}
\operatorname{Pr}(s, n) & =\operatorname{Pr}\left(t^{1} \leq W T P<t^{2}\right) \\
& =\operatorname{Pr}\left(t^{1} \leq z_{i}^{\prime} \beta+u_{i}<t^{2}\right) \\
& =\operatorname{Pr}\left(\frac{t^{1}-z_{i}^{\prime} \beta}{\sigma} \leq \frac{u_{i}}{\sigma}<\frac{t^{2}-z_{i}^{\prime} \beta}{\sigma}\right) \\
& =\varphi\left(\frac{t^{2}-z_{i}^{\prime} \beta}{\sigma}\right)-\varphi\left(\frac{t^{1}-z_{i}^{\prime} \beta}{\sigma}\right)
\end{aligned}
$$

where $t^{1}$ represents the suggested bid for the initial question and $t^{2}$ represents the suggested bid for the follow-up question. Given that Equation 6 follows $\operatorname{Pr}(a \leq X<b)=F(b)-F(a)$, using symmetry of the normal distribution, we can rearrange it once more to get the following:

$$
\operatorname{Pr}(s, n)=\varphi\left(z_{i}^{\prime} \frac{\beta}{\sigma}-\frac{t^{1}}{\sigma}\right)-\varphi\left(z_{i}^{\prime} \frac{\beta}{\sigma}-\frac{t^{2}}{\sigma}\right)
$$

The other two conditions can be similarly derived by replacing $t^{1} \leq W T P<t^{2}$ with $t^{2} \leq W T P<\infty$ for the yesyes scenario and $0 \leq W T P<t^{1}$ for the no scenario. Taken together, these scenarios comprise the censored likelihood function shown below:

$$
\begin{array}{r}
\sum_{i=1}^{N}\left[d_{i}^{s n} \ln \left(\varphi\left(z_{i}^{\prime} \frac{\beta}{\sigma}-\frac{t^{1}}{\sigma}\right)-\varphi\left(z_{i}^{\prime} \frac{\beta}{\sigma}-\frac{t^{2}}{\sigma}\right)\right)\right. \\
\left.+d_{i}^{s s} \ln \left(\varphi\left(z_{i}^{\prime} \frac{\beta}{\sigma}-\frac{t^{2}}{\sigma}\right)\right)+d_{i}^{n n} \ln \left(1-\varphi\left(z_{i}^{\prime} \frac{\beta}{\sigma}-\frac{t^{2}}{\sigma}\right)\right)\right]
\end{array}
$$

where $d_{i}^{s n}, d_{i}^{s s}$, and $d_{i}^{n n}$ represent indicator variables for yesno, yes-yes, and no-no, respectively. Depending on how the individual responds to the DC questions, the non-relevant indicator variables will take the value of zero, allowing only the relevant case to contribute to the likelihood function at any given time.

Censored regression analysis to estimate mean WTP for each of the four external attributes was conducted in $\mathrm{R}$ using the DCchoice package. The DCchoice package contains an oohbchoice function, which was specifically developed to execute maximum likelihood estimation on OOHB-DC data based on a number of required and optional arguments that the researcher specifies, such as the formula, distribution, and omission of missing data (Nakatani et al., 2016). The output is similar to that which is generated from the LIFEREG procedure on SAS v. 9.3, where parameter estimates can be directly interpreted as 


\section{Under the following prices, which edamame product would you choose?}

Non-GMO edamame pods at $\$ 3.50$ (10 oz. bag) USDA organic edamame pods at $\$ 3.75$ (10 oz. bag)

\section{7a. If you answered USDA organic edamame pods, choose which edamame product you would rather purchase:}

Non-GMO edamame pods at $\$ 3.50$ (10 oz. bag)

USDA organic edamame pods at $\$ 4.00(10 \mathrm{oz} . \mathrm{bag})$

\section{7b. If you answered Non-GMO edamame pods, would you be willing to pay anything above $\$ 3.50$ for USDA Organic edamame pods? \\ Yes \\ No}

FIGURE 3 | Example of OOHB-DC questions used in survey instrument.

changes in the marginal WTP (Neill and Williams, 2016). The three primary survey locations were coded into the model, while the other locations were used as the reference point. Mean WTP is calculated from each of the regressions based on the normal density function and calculated using marginal effects as in Neill and Holcomb (2019):

$$
E(W T P)=\Phi\left(\frac{x^{\prime} \beta}{\sigma}\right)\left[x^{\prime} \beta+\sigma\left(\frac{\phi\left(x^{\prime} \beta\right)}{\Phi\left(x^{\prime} \beta\right)}\right)\right] .
$$

A total of 222 surveys were collected, with 188 completed responses. While this is a small sample size as compared to many other consumer WTP studies, our sample has significant variation in education, income, and gender. For the OOHB-DC questions, only complete sets of responses (yes-no, yes-yes, or no-no) were used for the interval regression. A complete table of summary statistics can be seen in Table 2. Approximately $69 \%$ of the respondents were between the ages of 18 and 30 , and $34 \%$ of the respondents reported a household income below $\$ 20,000$, which can be attributed to the survey being distributed in a small college town where students are more prevalent in the community. The vast majority of respondents had received at least some level of secondary schooling, with $42 \%$ having taken some school, $25 \%$ having received a bachelor's degree, and $26 \%$ having received some sort of advanced or postgraduate degree. ${ }^{2}$ About $48 \%$ of the population were female. The majority of respondents were either Caucasian (57\%) or Asian (33\%). Approximately $44 \%$ of respondents indicated that they had a desire to reduce their meat consumption, of which $78 \%$ indicated health as a reason why and $56 \%$ indicated environment as a reason why. In regard to familiarity with edamame, $\sim 55 \%$ indicated that they were mostly (20\%) to extremely familiar (35\%) while another $42 \%$ indicated that they consume edamame at least once per week.

\footnotetext{
${ }^{2}$ Note that we test restricted versions of the model without education to determine if there is a high correlation between the variable and income. This was done via likelihood ratio tests, and a significant reduction in explanatory power was found.
}

\section{RESULTS AND DISCUSSION}

WTP estimates derived from the censored regression for all four attributes can be seen in Table 3. The interval regression estimated a mean WTP of $\sim \$ 4.34$ per $10 \mathrm{oz}$ for the fresh attribute. In other words, survey respondents indicated that they were willing to pay up to 84 cents more for edamame pods available fresh as opposed to frozen on average. The variables Female and Likelihood to shop local, significant at the $1 \%$ and $5 \%$ levels, respectively, both exhibited a negative effect on mean WTP for the fresh attribute. If the survey respondent was female, the average discount associated with fresh edamame is about 71 cents. This observation may be related to public uncertainty surrounding the safety of phytohormones in soy products for women's health (White et al., 2000; Duffy et al., 2007; Bar-El and Reifen, 2010; Cederroth et al., 2012), which are present in lower levels in frozen edamame products (Simonne et al., 2000). Meanwhile, the more likely a respondent was to shop local, the less they were willing to pay for a fresh edamame product. In other words, for a one-point increase in likelihood to shop local as indicated by respondents via a Likert scale, consumers discount the fresh edamame product by $\sim 34$ cents.

A considerable price discount was observed for edamame supplied as an on-the-stalk product. When given the choice between edamame supplied as pods and those supplied on the stalk, survey respondents were not willing to pay any more than $\$ 3.10$ per $10 \mathrm{oz}$. None of the covariates were significant in this case. For the certified organic attribute, only a small premium was observed; survey respondents indicated a maximum premium of 28 cents more for an edamame product labeled as USDA certified organic if an equivalent non-GMO product was also available. That is to say, beyond the non-GMO guarantee of their edamame product, respondents were not willing to pay appreciably more for the other provisions encompassed under the USDA-certified label. The only statistically significant variable was the participants' likelihood to purchase eco-labeled products.

The mean WTP estimate for the local attribute was similar to the estimate for the fresh attribute. When given a choice between local and non-local edamame pods, survey respondents indicated that they would be willing to pay an average of up to 85 cents 
TABLE 2 | Summary statistics for survey respondents.

\begin{tabular}{|c|c|c|c|c|}
\hline Variable & Description & $\begin{array}{l}\text { Percentage of } \\
\text { occurrence }\end{array}$ & Mean & $\begin{array}{l}\text { Standard } \\
\text { deviation }\end{array}$ \\
\hline \multirow[t]{5}{*}{ Location } & Location of the survey & & & \\
\hline & $1=$ Farmer's market & $31.08 \%$ & & \\
\hline & 2 = Supermarket & $16.67 \%$ & & \\
\hline & $3=$ Student center & $18.02 \%$ & & \\
\hline & $4=$ Other & $34.23 \%$ & & \\
\hline \multirow[t]{7}{*}{ Age } & Age of participant & & & \\
\hline & $1=$ Under 18 & $0.90 \%$ & 2.6347 & 1.213 \\
\hline & $2=18-30$ & $67.57 \%$ & & \\
\hline & $3=30-45$ & $13.06 \%$ & & \\
\hline & $4=46-50$ & $4.50 \%$ & & \\
\hline & $5=51-60$ & $6.31 \%$ & & \\
\hline & $6=$ Older than 60 & $5.86 \%$ & & \\
\hline \multirow[t]{3}{*}{ Gender } & Dummy variable & & & \\
\hline & $0=$ Male & $50.45 \%$ & 0.4886 & 0.501 \\
\hline & $1=$ Female & $48.20 \%$ & & \\
\hline \multirow[t]{6}{*}{ Ethnicity } & Categorical variable: & & & \\
\hline & 1 = Caucasian & $56.68 \%$ & & \\
\hline & $2=$ African American & $2.76 \%$ & & \\
\hline & $3=$ Asian & $33.18 \%$ & & \\
\hline & $4=$ Hispanic & $4.15 \%$ & & \\
\hline & $5=$ Other & $3.23 \%$ & & \\
\hline \multirow[t]{3}{*}{ Main shopper for household } & Dummy variable & & & \\
\hline & $0=\mathrm{No}$ & $36.92 \%$ & 0.6308 & 0.4837 \\
\hline & $1=$ Yes & $63.08 \%$ & & \\
\hline \multirow[t]{6}{*}{ Household size } & Number of people currently living in household: & & & \\
\hline & $1=1$ & $32.57 \%$ & 2.6284 & 1.4669 \\
\hline & $2=2$ & $20.18 \%$ & & \\
\hline & $3=3$ & $13.76 \%$ & & \\
\hline & $4=4$ & $18.81 \%$ & & \\
\hline & $5=$ More than 4 & $14.68 \%$ & & \\
\hline \multirow[t]{5}{*}{ Home food consumption } & $\begin{array}{l}\text { Number of meals consumed at home per } \\
\text { week: }\end{array}$ & & & \\
\hline & $1=1-5$ & $16.89 \%$ & 2.5707 & 0.9992 \\
\hline & $2=6-10$ & $29.68 \%$ & & \\
\hline & $3=11-15$ & $32.88 \%$ & & \\
\hline & $4=16$ or more & $20.55 \%$ & & \\
\hline \multirow[t]{6}{*}{ Education } & Highest level of education completed: & & & \\
\hline & $1=$ Some school & $1.39 \%$ & 3.6497 & 1.0031 \\
\hline & $2=$ High school diploma & $6.48 \%$ & & \\
\hline & $3=$ Some college & $41.67 \%$ & & \\
\hline & 4 = Bachelor's degree & $25.00 \%$ & & \\
\hline & $5=$ Advanced degree & $25.46 \%$ & & \\
\hline \multirow[t]{7}{*}{ Household income } & Household income levels: & & & \\
\hline & $1=<\$ 20,000$ & $34.91 \%$ & 3.1173 & 2.0375 \\
\hline & $2=\$ 20,000-\$ 35,000$ & $16.04 \%$ & & \\
\hline & $3=\$ 35,001-\$ 50,000$ & $9.43 \%$ & & \\
\hline & $4=\$ 50,001-\$ 70,000$ & $6.13 \%$ & & \\
\hline & $5=\$ 70,001-\$ 100,000$ & $10.85 \%$ & & \\
\hline & $6=$ More than $\$ 100,000$ & $22.64 \%$ & & \\
\hline
\end{tabular}


TABLE 2 | Continued

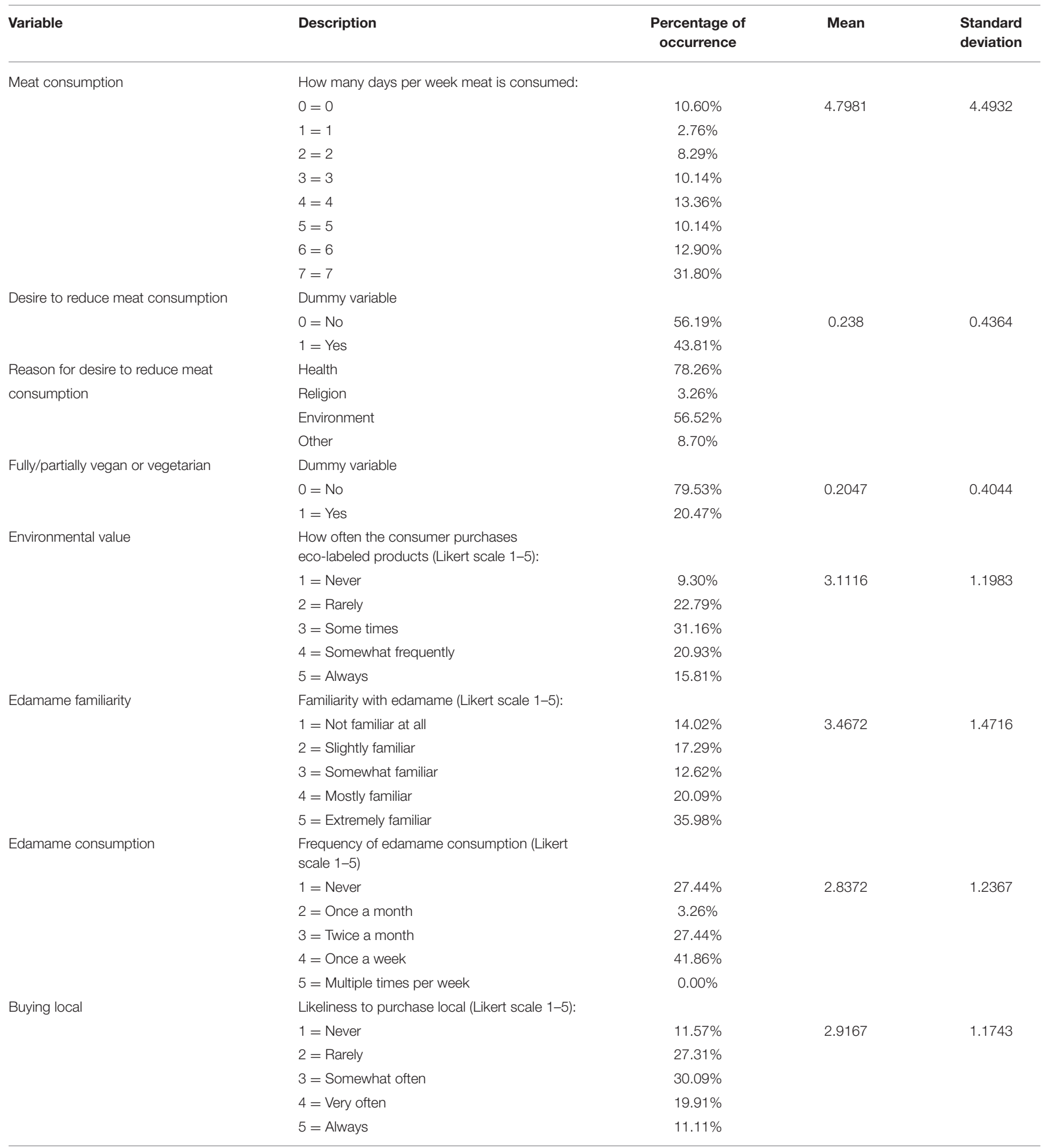

more for the local option. It should be noted that no formal definition of "local" regarding vicinity of production, state, or region was provided as part of the study. Nevertheless, a high mean WTP was observed. The Likelihood to purchase eco-labeled products variable appeared to have a significant effect on mean WTP for the local attribute, suggesting relatively broad interest in a local edamame product among our survey sample. There was also a negative WTP for both White and Asian participants as 
TABLE 3 | WTP estimates for edamame marketed as fresh, local, organic, and on the stalk $(N=188)$.

\begin{tabular}{|c|c|c|c|c|}
\hline Parameter & Fresh & Local & Organic & $\begin{array}{l}\text { On-the } \\
\text {-stalk }\end{array}$ \\
\hline Mean WTP (per 10 oz) & 4.34 & 4.35 & 3.78 & 3.10 \\
\hline Intercept & $4.118^{\star \star}$ & $6.192^{\star \star}$ & $4.445^{\star \star}$ & $3.167^{\star \star *}$ \\
\hline Location-Farmer's market & $0.856^{\star \star}$ & 0.319 & -0.051 & -0.067 \\
\hline Location-Supermarket & $1.221^{\star \star}$ & 0.289 & $0.608^{\star}$ & 0.105 \\
\hline Location-Student center & 0.292 & -0.368 & -0.338 & -0.180 \\
\hline Age & 0.007 & 0.223 & 0.081 & -0.006 \\
\hline Female & $-0.708^{\star \star}$ & 0.054 & -0.105 & -0.344 \\
\hline White & -0.103 & $-1.011^{\star \star}$ & 0.388 & 0.620 \\
\hline Asian & 0.043 & $-1.672^{\star \star}$ & -0.102 & 0.612 \\
\hline Shopper & -0.345 & 0.106 & 0.308 & -0.007 \\
\hline Household size & 0.041 & 0.036 & 0.062 & 0.058 \\
\hline Meals consumed at home & 0.070 & -0.107 & 0.155 & 0.096 \\
\hline Education & 0.079 & -0.029 & -0.012 & -0.078 \\
\hline Household income & -0.083 & 0.009 & -0.040 & -0.061 \\
\hline Meat consumption frequency & 0.009 & -0.005 & -0.003 & -0.043 \\
\hline $\begin{array}{l}\text { Desire to decrease meat } \\
\text { consumption }\end{array}$ & 0.002 & 0.204 & 0.044 & -0.079 \\
\hline Vegan/vegetarian & -0.013 & 0.206 & -0.389 & -0.570 \\
\hline $\begin{array}{l}\text { Purchase of eco-labeled } \\
\text { products }\end{array}$ & $0.336^{\star \star}$ & $0.285^{\star \star}$ & $0.320^{\star \star}$ & 0.128 \\
\hline $\begin{array}{l}\text { Edamame consumption } \\
\text { frequency }\end{array}$ & -0.133 & -0.103 & 0.061 & 0.078 \\
\hline Likelihood to shop local & $-0.260^{\star}$ & 0.082 & 0.024 & -0.123 \\
\hline $\mathrm{BID}$ & $-0.990^{\star \star}$ & $-1.487^{\star \star}$ & $-1.737^{\star \star}$ & $-1.070^{\star \star}$ \\
\hline Log likelihood & -149.37 & -124.37 & -167.85 & -142.95 \\
\hline
\end{tabular}

Asterisks " "**" and "*” indicate statistical significance at $1 \%$ and $5 \%$ levels, respectively.

compared to the "other" category. Asian participants discounted local more heavily as they likely have a higher preference for products imported from an Asian country where edamame originates and is commonly imported. This could also be due to consumers questioning the quality of locally produced edamame. Since they were not tasting local vs. imported edamame, there was likely some preconceived notion that domestically produced edamame does not meet the same taste/nutritional quality.

The variable Likelihood to purchase eco-labeled products was used in this study to gauge pro-environmental attitudes of the survey respondents. By including it as a parameter, our intention is to determine if pro-environmental attitudes have an impact on consumer WTP for the various attributes. In our results, we observe that Likelihood to purchase eco-labeled products consistently appeared to be a significant driver of mean WTP for three out of the four attributes studied. For each unit increase in pro-environmental attitudes indicated on the Likert scale, mean WTP increased by 32 cents for fresh edamame, 27 cents for local edamame, and 33 cents for USDA-certified organic edamame. The Likelihood to purchase eco-labeled products variable did not show statistical significance for the on-the-stalk attribute, which may be due to the fact that the on-the-stalk attribute is more related to physical appearance and, as a result, does not hold as many environmental implications as the other three attributes. These results follow a stream of literature suggesting that pro-environmental attitudes and beliefs continue to play an increasingly important role in consumer WTP for products (Umberger et al., 2009; Lusk et al., 2014; Neill and Williams, 2016; Rahman and Reynolds, 2017; Shin et al., 2017).

Survey location was a notable predictor of mean WTP observed for the fresh attribute in this study. In total, all surveys collected fell into one of four categories: those collected at the farmer's market, those collected at the local supermarket, those collected at the student center, and those collected from miscellaneous individuals around campus (henceforth referred to as "Misc. group"). We included the two purchasing locations (farmer's market and supermarket) and one non-purchasing location (student center) in our analysis and interpreted the results as they related to the Misc. group. Results showed that if a respondent completed the survey at the farmer's market, the mean WTP for the fresh attribute was 86 cents higher as compared to that in the Misc. group. Meanwhile, the mean WTP for surveys completed at the international supermarket was $\$ 1.22$ higher for the fresh attribute. For all attributes studied, the mean WTP for surveys collected at the student center-where no produce is sold and no sustainability claims are therefore madefailed to show significance. Here, we can clearly see that whether or not the survey was collected from a purchasing location largely influenced the premiums observed for the fresh attribute. Furthermore, the type of purchasing location (farmer's market vs. local supermarket) appeared to drastically impact the extent of the premiums observed for each of these attributes. While it is a bit surprising that we did not find location to be significant when it came to WTP for local edamame, this could be due to the fact that we did not define the geography to which being local represented. As Holcomb et al. (2018) noted, consumer preferences for local products are heavily dependent on how "local" is defined. A positive premium for organic edamame was found at the supermarket location.

\section{CONCLUSIONS}

With the hope of increased domestic production of edamame slowly becoming a reality, it is important to understand what factors can favor successful marketing efforts in the United States. In this study, we used the CV methodology to estimate the mean WTP for edamame marketed as fresh, local, and certified organic or as an on-the-stalk end product and then related these estimates to information on demographic information, dietary habits, and personal beliefs. Our results showed that fresh and local edamame held a significant marketing advantage over frozen products and non-local products, respectively. We also observed that despite its myriad of environmental provisions, edamame labeled as USDA certified organic may offer only limited marketing benefit to distributors if consumers already know that the edamame product that they are purchasing is non-GMO. This smaller premium must then be assessed at the cost of obtaining the organic certification. If the marginal cost of obtaining the organic certification is lower than the premium, then it 
would benefit the producer to pursue certification. In regard to end products, the convenience of pre-stripped edamame pods appears to take priority over the naturalness and freshness offered by an on-the-stalk or whole plant edamame product.

Several factors are important for understanding the domestic potential of alternatively marketed edamame. First, WTP for fresh edamame appears to be particularly influenced by demographic factors, especially gender. Meanwhile, personal beliefs such as pro-environmental attitudes appear to more consistently drive premiums for fresh, local, and organic edamame. This study also provides major evidence for the sorting effect that market venues have on consumer valuation of external attributes, especially for fresh edamame. These findings also highlight the importance of accounting for potential bias that can occur when collecting consumer intercept surveys from purchasing and non-purchasing locations.

Results from this study present important preliminary findings regarding the potential of alternatively marketed edamame in the domestic marketplace. Overall, these results support the continued growth of the domestic edamame industry. As with many WTP studies, our assertions are based on a single geographic location using a limited sample population, which may not be generally true in other states or regions across the United States. Therefore, future research should aim to substantiate these findings in other locations using different populations before producers and marketers make decisions. Given the hypothetical bias inherent in the CV methodology, non-hypothetical valuation methods may also serve to improve upon the results of this study by more accurately modeling consumer valuation of edamame based on real consequences. Another limitation of this study is that those who participated in the survey may have been predisposed to have a preference for edamame. While a large portion of our sample did not regularly consume edamame, it is still a concern that can limit the generalizability of the results. Future work could also focus on the combination of the attributes in this study. The goal of this study was to identify the individual attributes of interest,

\section{REFERENCES}

Bar-El, D. S., and Reifen, R. (2010). Soy as an endocrine disruptor: cause for caution? J. Pediatr. Endocrinol. Metab. 23, 855-861. doi: 10.1515/jpem. 2010.138

Bashi, Z., McCullough, R., Ong, L., and Ramirez, M. (2019). The market for alternative protein: Pea protein, cultured meat, and more $\mid$ McKinsey. New York, NY: McKinsey and Company. Available online at: https://www.mckinsey.com/ industries/agriculture/our-insights/alternative-proteins-the-race-for-marketshare-is-on (accessed January 5, 2021).

Bernard, J. C., Zhang, C., and Gifford, K. (2006). An experimental investigation of consumer willingness to pay for non-gm foods when an organic option is present. Agric. Resour. Econ. Rev. 35, 1-12. doi: 10.1017/S1068280500006808

Bernick, K. (2009). Edamame Takes Root in U.S. Corn and Soybean Digest. 24 Feb. 2018. Available online at: http://cornandsoybeandigest.com/edamame-takesroot-us (accessed January 5, 2021).

Beyan, S. M., Wolde-meskel, E., and Dakora, F. D. (2018). An assessment of plant growth and $\mathrm{N} 2$ fixation in soybean genotypes grown in uninoculated soils collected from different locations in Ethiopia. but the combination of attributes may have non-linear effects on WTP. As edamame variety development continues, there may be additional opportunities to study consumer WTP for edamame on the basis of sensory characteristics such as quality, flavor profile, and appearance as well. While further work is needed to validate the WTP values extracted from our sample, the information garnered from this study does serve as a reference for future studies on domestic edamame demand.

\section{DATA AVAILABILITY STATEMENT}

The raw data supporting the conclusions of this article will be made available by the authors, without undue reservation.

\section{ETHICS STATEMENT}

The studies involving human participants were reviewed and approved by Virginia Tech Institutional Review Board. The patients/participants provided their written informed consent to participate in this study.

\section{AUTHOR CONTRIBUTIONS}

NL drafted the manuscript and edited based on co-author comments. All authors reviewed, edited, and approved the draft and submitted versions of the manuscript.

\section{FUNDING}

This work was funded, in part, by USDA-NIFA, Grant No. 2018-51181-28384, Accession No. 1016465, and the Virginia Agricultural Experiment Station.

\section{ACKNOWLEDGMENTS}

The authors thank USDA-NIFA and Virginia Agricultural Experiment Station for the financial support.
Symbiosis (Philadelphia, PA) 75, 189-203. doi: 10.1007/s13199-0180540-9

Born, H. (2006). Edamame: Vegetable soybean. National Center for Appropriate Technology (NCAT) a Publication of ATTRA-National Sustainable Agriculture Information Service. Paul Driscoll (Ed.) Available online at: http://Attra.Ncat.Org/Attrapub/PDF/Edamame.Pdf (accessed June $25,2009)$.

Brown, C. (2003). Consumers' preferences for locally produced food: a study in southeast Missouri. Am. J. Altern. Agric. 18, 213-224. doi: 10.1079/AJAA2 00353

Brunner, T. A., van der Horst, K., and Siegrist, M. (2010). Convenience food products. Drivers for consumption. Appetite 55, 498-506. doi: 10.1016/j.appet.2010.08.017

Candel, M. J. (2001). Consumers' convenience orientation towards meal preparation: conceptualization and measurement. Appetite 36, 15-28. doi: 10.1006/appe.2000.0364

Carpio, C. E., and Isengildina-Massa, O. (2009). Consumer willingness to pay for locally grown products: the case of South Carolina. Agribusiness 25, 412-426. doi: 10.1002/agr.20210 
CBS News (2013, March 29). Edamame: is the future of American soy farmers' profits in edible soy beans for people? Available online at: https://www. cbsnews.com/news/edamame-is-the-future-of-american-soy-farmersprofits-in-edible-soy-beans-for-people/ (accessed January 5, 2021).

Cederroth, C. R., Zimmermann, C., and Nef, S. (2012). Soy, phytoestrogens and their impact on reproductive health. Mol. Cell. Endocrinol. 355, 192-200. doi: 10.1016/j.mce.2011.05.049

Cooper, J. C., Hanemann, M., and Signorello, G. (2002). One-and-one-halfbound dichotomous choice contingent valuation. Rev. Econ. Stat. 84, 742-750. doi: 10.1162/003465302760556549

Dettmann, R. L., and Dimitri, C. (2009). Who's Buying organic vegetables? demographic characteristics of U.S. consumers. J. Food Prod. Mark. 16, 79-91. doi: 10.1080/10454440903415709

Di Vita, G., Zanchini, R., Falcone, G., D’Amico, M., Brun, F., and Gulisano, G. (2021). Local, organic or protected? detecting the role of different quality signals among Italian olive oil consumers through a hierarchical cluster analysis. J. Clean. Prod. 290:125795. doi: 10.1016/j.jclepro.2021.1 25795

Duffy, C., Perez, K., and Partridge, A. (2007). Implications of Phytoestrogen Intake for Breast Cancer. CA Cancer J. Clin. 57, 260-277. doi: 10.3322/CA.5 7.5.260

Fan, X., Gómez, M. I., and Coles, P. S. (2019). Willingness to pay, quality perception, and local foods: the case of broccoli. Agric. Resour. Econ. Rev. 48, 414-432. doi: 10.1017/age.2019.21

Feldmann, C., and Hamm, U. (2015). Consumers' perceptions and preferences for local food: a review. Food Qual. Prefer. 40, 152-164. doi: 10.1016/j.foodqual.2014.09.014

Garber, B., and Neill, C. (2019). Edamame: Costs, Revenues, and Profitability. Blacksburg, VA: Virginia Cooperative Extension.

Govindasamy, R., Van Vranken, R., Sciarappa, W., Ayeni, A., Puduri, V. S., Pappas, K., et al. (2010). Ethnic crop opportunities for growers on the east coast: a demand assessment. J. Ext. 48, 1-9.

Haghiri, M., Hobbs, J. E., and McNamara, M. L. (2009). Assessing consumer preferences for organically grown fresh fruit and vegetables in eastern new brunswick. Int. Food Agribus. Manag. Rev. 12, 1-20. doi: 10.22004/ag.econ.92556

Hanemann, M., Loomis, J., and Kanninen, B. (1991). Statistical efficiency of double-bounded dichotomous choice contingent valuation. Am. J. Agric. Econ. 73, 1255-1263. doi: 10.2307/1242453

Hasler, C. M. (2002). The cardiovascular effects of soy products. J. Cardiovasc. Nurs. 16, 50-63. doi: 10.1097/00005082-200207000 $-00006$

Heinrichs, P. A. (2016). Consumer preferences and willingness to pay for fresh and frozen vegetables. Champaign, IL: University of Illinois at Urbana-Champaign. Available online at: https://pdfs.semanticscholar.org/02fa/ c09206b0db3db090197ed217d2ba47842c5c.pdf (accessed January 5, 2021).

Holcomb, R. B., Neill, C. L., Lelekacs, J., Velandia, M., Woods, T. A., Goodwin, J.r, H. L., et al. (2018). A local food system glossary: a rose by any other name. Choices 33, 1-8. doi: 10.22004/ag.econ.2 76057

Jaeger, A. (2019). Arkansas Has Unsuspected Might in Edamame Market. Available online at: https://www.thv11.com/article/news/edamame/91-56781308-85d24e7d-9242-6afef0712996 (accessed January 5, 2021).

Lockie, S., Lyons, K., Lawrence, G., and Grice, J. (2004). Choosing organics: a path analysis of factors underlying the selection of organic food among Australian consumers. Appetite 43, 135-146. doi: 10.1016/j.appet.2004.02.004

Lopez-Feldman, A. (2012). Introduction to Contingent Valuation Using Stata. 17. College Station, TX: Stata Press; StataCorp.

Lord, N., Neill, C., and Zhang, B. (2019a). Production and Economic Considerations for Fresh Market Edamame in Southwest Virginia. Blacksburg, VA: Virginia Tech.

Lord, N., Zhang, B., Kuhar, T., Carneiro, R., Sutton, K., and Yu, D. (2019b). USDA Edamame Project. Blacksburg, VA: Virginia Cooperative Extension. Available online at: https://www.pubs.ext.vt.edu/content/dam/pubs_ext_vt_ edu/spes/SPES-104/SPES-104.pdf (accessed January 5, 2021).

Lusk, J. L., Schroeder, T. C., and Tonsor, G. T. (2014). Distinguishing beliefs from preferences in food choice. Eur. Rev. Agric. Econ. 41, 627-655. doi: 10.1093/erae/jbt035
Martinez, S. (2010). Local Food Systems; Concepts, Impacts, and Issues. Collingdale, PA: DIANE Publishing.

Michelfelder, A. J. (2009). Soy: a complete source of protein. Am. Fam. Physician $79,43-47$.

Nakatani, T., Aizaki, H., and Sato, K. (2016). oohbchoice: Parametric Approach to Analyze One And-One-Half-Bound... in DCchoice: Analyzing Dichotomous Choice Contingent Valuation Data. Available online at: https://rdrr.io/cran/ DCchoice/man/oohbchoice.html (accessed January 5, 2021).

Neill, C. L., and Holcomb, R. B. (2019). Does a food safety label matter? consumer heterogeneity and fresh produce risk perceptions under the food safety modernization act. Food Policy 85, 7-14. doi: 10.1016/j.foodpol.2019. 04.001

Neill, C. L., Holcomb, R. B., and Lusk, J. L. (2020). Potential beggar-thyneighbor effects of state branding programs. Agribus. Int. J. 36, 3-19. doi: 10.1002/agr.21625

Neill, C. L., and Williams, R. B. (2016). Consumer preference for alternative milk packaging: the case of an inferred environmental attribute. J. Agric. Appl. Econ. 48, 241-256. doi: 10.1017/aae.2016.17

Onozaka, Y., Nurse, G., and McFadden, D. T. (2011). Defining sustainable food market segments: do motivations and values vary by shopping locale? Am. J. Agric. Econ. 93, 583-589. doi: 10.1093/ajae/ aaq152

Owusu, V., and Owusu Anifori, M. (2013). Consumer willingness to pay a premium for organic fruit and vegetable in Ghana. Int. Food Agribus. Manag. Rev. 16, 1-20, doi: 10.22004/ag.econ.144649

Penn, J., and $\mathrm{Hu}, \mathrm{W}$. (2018). Understanding hypothetical bias: An enhanced meta-analysis. Am. J. Agric. Econ. 100, 1186-1206. doi: 10.1093/ajae/ aay021

Pollack, S. L. (2001). Consumer demand for fruit and vegetables: the US example. Chang. Struct. Glob. Food Consum. Trade 6, 49-54.

Rahman, I., and Reynolds, D. (2017). Organic wine: the influence of biospheric, altruistic, and egoistic values on purchase intention, willingness to pay more, and willingness to sacrifice. Int. J. Hosp. Beverage Manag. 1:1. doi: $10.34051 / \mathrm{j} / 2019.1$

Sharma, K. P. (2013). Varietal Yield Stability and Appropriate Management for Quality Organic Edamame Production. Vernon, BC: Organic BC.

Shin, Y. H., Moon, H., Jung, S. E., and Severt, K. (2017). The effect of environmental values and attitudes on consumer willingness to pay more for organic menus: a value-attitude-behavior approach. J. Hosp. Tour. Manag. 33, 113-121. doi: 10.1016/j.jhtm.2017.10.010

Shockley, J. M., Dillon, C. R., and Woods, T. A. (2011). Estimating the Economic Viability of a New Crop Alternative for the US Organic Market: Edamame-a Vegetable Soybean. Pittsburgh, PA: Agricultural and Applied Economics Association.

Shurtleff, W., and Aoyagi, A. (2009). History of Edamame, Green Vegetable Soybeans, and Vegetable-Type Soybeans (1275-2009): Extensively Annotated Bibliography and Sourcebook. Lafayette, CA: Soyinfo Center.

Simonne, A. H., Smith, M., Weaver, D. B., Vail, T., Barnes, S., and Wei, C. I. (2000). Retention and changes of soy isoflavones and carotenoids in immature Soybean Seeds (Edamame) during processing. J. Agric. Food Chem. 48, 6061-6069. doi: $10.1021 /$ jf000247f

Stevens-Garmon, J., Huang, C. L., and Lin, B.-H. (2007). Organic demand: a profile of consumers in the fresh produce market. Choices 22, 109-115.

Taku, K., Umegaki, K., Sato, Y., Taki, Y., Endoh, K., and Watanabe, S. (2007). Soy isoflavones lower serum total and LDL cholesterol in humans: a metaanalysis of 11 randomized controlled trials. Am. J. Clin. Nutr. 85, 1148-1156. doi: $10.1093 / \mathrm{ajcn} / 85.4 .1148$

Umberger, W. J., McFadden, D. D. T., and Smith, A. R. (2009). Does altruism play a role in determining U.S. consumer preferences and willingness to pay for natural and regionally produced beef? Agribusiness 25, 268-285. doi: 10.1002/agr.20194

Venkatachalam, L. (2004). The contingent valuation method: a review. Environ. Impact Assess. Rev. 24, 89-124. doi: 10.1016/S0195-9255(03) 00138-0

Wang, Q., Sun, J., and Parsons, R. (2010). Consumer preferences and willingness to pay for locally grown organic apples: evidence from a conjoint study. HortScience 45, 376-381. doi: 10.21273/HORTSCI.45.3.376 
White, L. R., Petrovitch, H., Ross, G. W., Masaki, K., Hardman, J., Nelson, J., et al. (2000). Brain aging and midlife tofu consumption. J. Am. Coll. Nutr. 19, 242-255. doi: 10.1080/07315724.2000.107 18923

Wolfe, E., Popp, M., Bazzani, C., Nayga Jr, R. M., Danforth, D., Popp, J., et al. (2018). Consumers' willingness to pay for edamame with a genetically modified label. Agribusiness 34, 283-299. doi: 10.1002/agr. 21505

Conflict of Interest: The authors declare that the research was conducted in the absence of any commercial or financial relationships that could be construed as a potential conflict of interest.
Publisher's Note: All claims expressed in this article are solely those of the authors and do not necessarily represent those of their affiliated organizations, or those of the publisher, the editors and the reviewers. Any product that may be evaluated in this article, or claim that may be made by its manufacturer, is not guaranteed or endorsed by the publisher.

Copyright (c) 2021 Lord, Zhang and Neill. This is an open-access article distributed under the terms of the Creative Commons Attribution License (CC BY). The use, distribution or reproduction in other forums is permitted, provided the original author(s) and the copyright owner(s) are credited and that the original publication in this journal is cited, in accordance with accepted academic practice. No use, distribution or reproduction is permitted which does not comply with these terms. 